\title{
Reproductive aspects and knowledge of family planning among women with Acquired Immunodeficiency Syndrome
}

\author{
Aspectos reprodutivos e conhecimento sobre planejamento familiar \\ de mulheres com Síndrome da Imunodeficiência Adquirida \\ Aspectos reproductivos y conocimiento sobre planificación familiar \\ de mujeres con Síndrome de Inmunodeficiencia Adquirida
}

Ivana Cristina Vieira de Lima' ${ }^{1}$ Maria da Conceição dos Santos Oliveira Cunha², Gilmara Holanda da Cunha ${ }^{3}$, Marli Teresinha Gimeniz Galvão ${ }^{3}$

How to cite this article:

Lima ICV, Cunha MCSO, Cunha GH, Galvão MTG. Reproductive aspects and knowledge of family planning among women with Acquired Immunodeficiency Syndrome. Rev Esc Enferm USP. 2017;51:e03224. http://dx.doi.org/10.1590/S1980-220X2016039403224

1 Universidade Federal do Ceará, Programa de Pós-Graduação em Enfermagem, Fortaleza, CE, Brazil.

2 Universidade Federal do Ceará, Faculdade de Farmácia, Odontologia e Enfermagem, Fortaleza, CE, Brazil.

3 Universidade Federal do Ceará, Departamento de Enfermagem, Fortaleza, CE, Brazil.

\begin{abstract}
Objective: To analyze the reproductive aspects and knowledge of family planning among women with Acquired Immunodeficiency Syndrome (AIDS). Method: Crosssectional and descriptive study carried out from January to December, 2015, in the outpatient care of infectious disease unit in a hospital located in Fortaleza, Ceará. Data were collected through a form applied by interview in a private setting. Results: 102 women participated in the study. Most were aware that they were serologically positive with human immunodeficiency virus (HIV) during prenatal care (96.1\%) and did not intend to have more children (63.7\%). Women who were less than 39 years of age, had a higher educational level, and a shorter time of antiretroviral therapy had better chances of having children $(p \leq 0.05)$. Having a steady partner increased the chance of desiring to have children, while tubal ligation was higher among women that did not receive counseling on family planning. Knowledge of family planning was limited because of lack of assistance provided by health professionals.
\end{abstract}

\section{DESCRIPTORS}

HIV; Acquired Immunodeficiency Syndrome; Reproduction; Contraception; Family Planning. 


\section{INTRODUCTION}

There are 36.7 million people around the world living with acquired immunodeficiency syndrome (HIV), and the number of infected women represents more than half of this population ${ }^{(1)}$. Access to antiretroviral therapy (ART) has been significantly expanded, providing improvement in the quality of life and an increase in survival rates for people with HIV and Acquired Immunodeficiency Syndrome (AIDS), and raised challenges aimed at guaranteeing total health for these individuals ${ }^{(1-2)}$. In this regard, a decrease in morbimortality and an increase in the number of women of reproductive age with HIV/AIDS have been seen, which led to broadening the discussion on family planning ${ }^{(2-3)}$, with the aim of maintaining the health of women, safeguarding reproductive rights, avoiding unintended pregnancy and maternal death, and preventing virus spread and vertical transmission ${ }^{(4)}$.

Brazil is renowned for having a national program for HIV/AIDS that guarantees antiretroviral drugs free of charge and sustainably for everyone with HIV/AIDS, including pregnant women, in addition to offering quick testing and serology for detecting HIV in pregnant women ${ }^{(5)}$. Despite these achievements, there are social inequalities among the regions of Brazil related to virus detection rate in this population. In the Northeast region, detection rates for HIV are the lowest, and pregnant women have the poorest education and hence are the most affected in the country ${ }^{(6)}$. As a consequence, there is a lack of information about the factors that affect the wish to have children among these women, as well as the use of contraceptive methods, in this Brazilian region.

Evidence suggests that, despite the possibility of women with HIV/AIDS having a healthy and reasonable sexual and reproductive life, there are challenges related to access to sexual and reproductive rights and health services, including the provision of contraceptive methods ${ }^{(7)}$. Furthermore, barriers such as lack of female decision power, a shortage of human and material resources, and poor quality of family planning services increase women's vulnerability related to reproductive aspects.

Most studies on the reproductive aspects of women with HIV/AIDS were developed in African nations ${ }^{(8-10)}$, where the highest incidence of cases is concentrated. It is important to emphasize that the Brazilian scenario is not different, taking into account that it concentrates the highest number of HIV/AIDS cases in Latin America ${ }^{(11)}$, which exposes the need to evaluate the reproductive aspects of these women. Based on the above considerations, the objective of this study was to analyze the reproductive aspects and knowledge of family planning among women with AIDS.

\section{METHOD}

This was a cross-sectional, descriptive, and quantitative study developed in the infectious disease outpatient unit of a university hospital in Fortaleza, state of Ceará, Brazil from January to December, 2015. The referred hospital assists adult patients with HIV/AIDS, and provides ART, laboratory exams and imaging, and condoms. Taking into account the population of women with AIDS monitored by the health service during the study period, the following formula for a finite population sample calculation was applied:

$$
n=\frac{z^{2} \cdot p \cdot(1-p) \cdot N}{\varepsilon^{2} \cdot(N-1)+z^{2} \cdot p \cdot(1-p)}
$$

In this formula, $z$ is equal to the statistical value of $z$ (1.96) for confidence level adopted (95\%) and $p, N$ e $\varepsilon$ correspond to the presumed prevalence $(0.50)$ for the population of women monitored by the service (135) and for the tolerable error (0.05), respectively. Therefore, a sample of 102 patients was calculated.

The inclusion criteria were: women with AIDS; age equal or greater than 18 years; and regardless they had a sexual partner (steady or casual). Pregnant women and those under conditions that could interfere with the comprehension of the researched information were excluded. Convenience sampling method was used for selecting the participants, and women were invited to participate in the study as they showed up at the care service for their appointments. For data collection, interviews of 50 minutes' duration were conducted in a private setting, applying a form with the variables: social-demographic and clinical data; contraceptive methods in use; reproductive background; and family planning knowledge.

Absolute and relative frequency, average, and standard deviation (SD) for the quantitative variables were calculated. Statistical associations as dependent variables were considered: wish to have children; whether they have children; counseling on family planning while living with HIV. In addition were the answers to the questions: With HIV, is possible to have children? Can a seroconcordant couple have children? The remaining variables were listed as independent. The association between the categorical variables was carried out with the chi-squared test for the independent variables, odds ratio (OR) value, and a confidence interval (CI) of $95 \%$. A p-value of $<0.05$ value was considered statistically significant. Data were tabulated using Excel software and analyzed with software $\mathrm{R}$, version 3.2.2.

The study was in conformity with the ethical and legal aspects of Resolution no 466/2012 of the National Health Council regarding studies that involve human beings. The research was approved by the Ethics Research Committee of Walter Cantídio University Hospital on March, 9, 2015, under approval number 992.484 .

\section{RESULTS}

Out of the 102 studied women, more than half were less than 39 years of age (56.9\%), (average \pm SD: $37.3 \pm$ 6.4), with an educational level equal to or greater than 10 years $(59.8 \%)$ (average \pm SD: $9.7 \pm 3.6$ ). The majority were Catholic (66.7\%), married (67.6\%), employed (52.0\%), had a household income equal to or less than two minimum wages $(80.4 \%)$, with a diagnosis time equal to or greater than 37 months (82.4\%), and ART time equal to or less than five years $(57.1 \%)$ (Table 1 ). 
Table 1 - Socio-demographic and clinical characterization of 102 women living with AIDS - Fortaleza, Ceará, Brazil, Jan./Dec. 2015

\begin{tabular}{ll}
\hline Socio-demographic and clinical variables & $\mathrm{N}(\%)$ \\
\hline Age (in years) & $58(56.9)$ \\
$<39$ & $44(43.1)$ \\
$\geq 40$ & \\
\hline Education (in years) & $41(40.2)$ \\
$<9$ & $52(59.8)$ \\
$\geq 10$ & \\
\hline Marital status & $69(67.6)$ \\
Married & $33(32.4)$ \\
\hline Single/divorced/separated/widowed & $68(66.7)$ \\
\hline Religion & $34(33.3)$ \\
Catholic & \\
Other (Evangelical/Spiritism/without religion) & $53(52.0)$ \\
\hline Occupational status & $49(48.0)$ \\
\hline Employed & \\
Unemployed/retired & $82(80.4)$ \\
\hline Monthly household income (in minimum wages) & \\
$\leq 2$ & $20(19.6)$ \\
$>2$ & $64(57.1)$ \\
\hline Diagnostic time of positive anti-HIV serology (in months) & \\
$<36$ & $38(42.9)$ \\
\hline Time of antiretroviral therapy use (in years) & \\
$<5$ & \\
\hline & \\
&
\end{tabular}

Most were diagnosed with HIV during the prenatal period (96.1\%), and after the birth of a child exposed to HIV, more than half $(63.7 \%)$ decided not to have more children. The majority had children at the time of the interview $(84.3 \%)$, with a predominance of one to two children (51.9\%), and only one revealed that the anti-HIV serology of her child was positive. Most had a steady partner (75.0\%) that knew of her serological situation (73.5\%). The use of male condoms (58.8\%) and poor use of oral contraceptives (23.5\%) were highlighted (Table 2).

Table 2 - Reproductive background and contraceptive use of 102 women living with AIDS - Fortaleza, Ceará, Brazil, Jan./Dec. 2015

\begin{tabular}{l}
\hline $\begin{array}{l}\text { Reproductive background and use of contraceptive } \\
\text { methods }\end{array}$ \\
\hline
\end{tabular}

Detection of positive anti-HIV serology during prenatal

\begin{tabular}{lc} 
Yes & $98(96.1)$ \\
No & $4(3.9)$ \\
\hline Women wishing to have child & \\
Yes & $37(36.3)$ \\
No & $65(63.7)$ \\
\hline Have children & $86(84.3)$ \\
Yes & $16(15.7)$ \\
No & continued...
\end{tabular}

\begin{tabular}{lc}
$\begin{array}{l}\text { Reprodinuation } \\
\text { methods }\end{array}$ & N (\%) \\
\hline Number of children & $16(15.7)$ \\
0 & $35(34.3)$ \\
1 & $18(17.6)$ \\
2 & $33(32.4)$ \\
\hline$\geq 3$ & \\
\hline Children with positive anti-HIV serology & $1(1.0)$ \\
Yes & $96(99.0)$ \\
No & \\
\hline Steady sexual partner* & $72(75.0)$ \\
Yes & $14(25.0)$ \\
No & \\
\hline Partner knows serological status of the woman & $75(73.5)$ \\
Yes & $24(23.5)$ \\
No & \\
\hline Use of male condom & $60(58.8)$ \\
Yes & $42(41.2)$ \\
\hline No & \\
\hline Tubal ligation & $24(23.5)$ \\
Yes & $78(76.5)$ \\
\hline No & \\
Yes & \\
No & \\
\hline
\end{tabular}

*Those with an affective-sexual relationship for at least three months.

Despite the fact that the majority of the women believed that they might have to have children living with AIDS (78.4\%), only one-third (33.3\%) revealed having received counseling on family planning, while more than half were not aware of the forms of vertical transmission (55.9\%). Regarding the influence of the partner's serology in terms of conception, most believed that seroconcordants could have children (53.9\%), but serodiscordants could not (52.0\%) (Table 3).

Table 3 - Knowledge of family planning of 102 women living with AIDS - Fortaleza, Ceará, Brazil, Jan./Dec. 2015

\begin{tabular}{lc}
\hline Knowledge of family planning & N (\%) \\
\hline Did receive counseling on family planning while living with HIV? \\
Yes & $34(33.3)$ \\
No & $68(66.7)$ \\
\hline Those with HIV can have children? & $80(78.4)$ \\
Yes & $22(21.6)$ \\
No & $45(44.1)$ \\
\hline Knows the forms of prevention against HIV vertical transmission? & $57(55.9)$ \\
\hline Yes & $49(48.0)$ \\
No & $53(52.0)$ \\
\hline Can women with HIV and serodiscordant* partners have children? \\
Yes \\
No & $55(53.9)$ \\
\hline Can women with HIV and seroconcordant+ partners have children? & $48(46.1)$ \\
\hline Yes & \\
No & *Serodiscordant: partner with negative anti-HIV serology; †Seroconcordant: partner \\
with positive anti-HIV serology & \\
&
\end{tabular}


Women with steady partners had a higher chance of wishing to have children ( $\mathrm{p}=0.04$; OR=1.34; CI 95\%=0.44.9), but those with one or more children ( $\mathrm{p}=0.01 ; \mathrm{OR}=1.50$; CI 95\%=0.4-5.2) or who had undergone tubal ligation $(\mathrm{p}=0.01 ; \mathrm{OR}=0.16$; CI 95\%=0.0-0.6) had decided not to have more children. Tubal ligation was higher in women that did not receive counseling on family planning while living with HIV ( $\mathrm{p}=0.03 ; \mathrm{OR}=5.35 ;$ CI 95\%=1.4-38.4) (Table 4).

Table 4 - Reproductive background and contraceptive methods associated with the desire to have children of 102 women living with AIDS - Fortaleza, Ceará, Brazil, Jan./Dec. 2015.

\begin{tabular}{|c|c|c|c|c|c|c|c|c|}
\hline \multirow{2}{*}{ Variables } & \multicolumn{2}{|c|}{ Desire to have children } & \multirow{2}{*}{$\mathbf{p}$} & \multirow{2}{*}{$\mathrm{ORt}, \mathrm{Cl}$} & \multicolumn{2}{|c|}{$\begin{array}{c}\text { Counseling on family planning } \\
\text { while living with HIV }\end{array}$} & \multirow{2}{*}{ p } & \multirow{2}{*}{$\mathrm{ORt}, \mathrm{Cl}$} \\
\hline & Yes(n) & No(n) & & & Yes(n) & No(n) & & \\
\hline \multicolumn{9}{|c|}{ Number of children } \\
\hline 0 & 9 & 7 & \multirow[t]{4}{*}{$0.01^{*}$} & 1.0 & 7 & 9 & \multirow[t]{4}{*}{0.08} & \\
\hline 1 & 16 & 19 & & $1.50(0.4-5.2)$ & 16 & 19 & & \\
\hline 2 & 7 & 11 & & $1.97(0.5-8.3)$ & 3 & 15 & & - \\
\hline$\geq 3$ & 5 & 28 & & $6.75(1.7-29.6)$ & 8 & 25 & & \\
\hline \multicolumn{9}{|c|}{ Steady sexual partner } \\
\hline Yes & 31 & 41 & \multirow[t]{2}{*}{$0.04^{*}$} & 1.0 & 25 & 47 & \multirow[t]{2}{*}{0.89} & \\
\hline No & 6 & 24 & & $2.94(1.1-8.9)$ & 4 & 10 & & \\
\hline \multicolumn{9}{|c|}{ Tubal ligation } \\
\hline Yes & 2 & 18 & \multirow[t]{2}{*}{$0.01^{*}$} & 1.0 & 32 & 50 & \multirow[t]{2}{*}{$0.03 *$} & 1.0 \\
\hline No & 35 & 47 & & $0.16(0.0-0.6)$ & 2 & 18 & & $5.35(1.4-38.4)$ \\
\hline
\end{tabular}

${ }^{*} \mathrm{p}<0.05$; †odds ratio; $\neq$ Confidence interval

Women of age $\leq 39$ years and with a higher educational level had better chances of receiving correct information about the possibility of having children while living with $\mathrm{HIV}(\mathrm{p}=0.01$; $\mathrm{OR}=0.22 ; \mathrm{CI} 95 \%=0.1-0.6$ ). These same women answered that seroconcordant couples could have children $(\mathrm{p}=0.00$ $\mathrm{OR}=0.27$; CI $95 \%=0.1-0.6)$. The "have children" variable showed a statistically significant association with age $(\mathrm{p}=0.05$; $\mathrm{OR}=3.44$; CI 95\% = $1.1-12.0)$, educational level $(\mathrm{p}=0.04$; $\mathrm{OR}=5.61 ; \mathrm{CI} 95 \%=1.4-41.0)$, and ART time $(\mathrm{p}=0.01$; $\mathrm{OR}=0.11 ; \mathrm{CI} 95 \%=0.0-0.6)$. That is to say, women of age $\leq 39$ years, higher educational level, and ART time of use less than or equal to five years had better chances of having children (Table 5).

Table 5 - Socio-demographic and clinical aspects associated with the reproductive background, use of contraceptive and knowledge of family planning among 102 women living with AIDS - Fortaleza, Ceará, Brazil, Jan./Dec. 2015

\begin{tabular}{|c|c|c|c|c|c|c|c|c|c|c|c|c|c|c|c|c|}
\hline \multirow[t]{2}{*}{ Variables } & \multicolumn{2}{|c|}{ Have Children } & \multirow[t]{2}{*}{$\mathbf{p}$} & \multirow[t]{2}{*}{$\mathrm{OR}+, \mathrm{CI}$} & \multicolumn{2}{|c|}{$\begin{array}{l}\text { Desire to have } \\
\text { children }\end{array}$} & \multirow[t]{2}{*}{$\mathbf{p}$} & \multirow[t]{2}{*}{$\begin{array}{c}\text { ORt, } \\
\text { Cl¥ }\end{array}$} & \multicolumn{2}{|c|}{$\begin{array}{l}\text { Those with } \\
\text { HIV can have } \\
\text { children? }\end{array}$} & \multirow[t]{2}{*}{$\mathbf{p}$} & \multirow[t]{2}{*}{ ORt/CIF } & \multicolumn{2}{|c|}{$\begin{array}{l}\text { Can serocon- } \\
\text { cordant couple } \\
\text { have children? }\end{array}$} & \multirow{2}{*}{$\mathbf{p}$} & \multirow[t]{2}{*}{$\mathrm{OR}+, \mathrm{Cl}$} \\
\hline & Yes(n) & No(n) & & & Yes(n) & No(n) & & & Yes(n) & $\operatorname{No}(n)$ & & & Yes(n) & No(n) & & \\
\hline \multicolumn{17}{|l|}{ Age } \\
\hline$\leq 39$ & 53 & 5 & $0.05^{*}$ & 1.0 & 24 & 34 & 0.30 & - & 47 & 11 & 0.62 & - & 30 & 28 & 0.76 & - \\
\hline$\geq 40$ & 33 & 11 & & $\begin{array}{c}3.44 \\
(1.1-12.0)\end{array}$ & 13 & 31 & & - & 33 & 11 & & - & 25 & 19 & & - \\
\hline \multicolumn{17}{|c|}{ Educational level (years) } \\
\hline$\leq 9$ & 39 & 2 & $0.03 *$ & 1.0 & 11 & 30 & 0.16 & - & 26 & 15 & $0.01 *$ & 1.0 & 14 & 27 & $0.002 *$ & 1.0 \\
\hline$\geq 10$ & 47 & 14 & & $\begin{array}{c}5.40 \\
(1.4-39.2)\end{array}$ & 26 & 35 & & - & 48 & 6 & & $\begin{array}{c}0.22 \\
(0.1-0.6)\end{array}$ & 41 & 20 & & $\begin{array}{c}0.26 \\
(0.1-0.6)\end{array}$ \\
\hline \multicolumn{17}{|c|}{ Monthly household income (in minimum wages) } \\
\hline$\leq 2$ & 69 & 13 & $>0.99$ & - & 30 & 52 & $>0.99$ & - & 62 & 20 & 0.27 & $\begin{array}{c}0.32 \\
(0.0-2.3)\end{array}$ & 43 & 39 & 0.72 & - \\
\hline$>2$ & 17 & 3 & & - & 7 & 13 & & - & 18 & 2 & & - & 12 & 8 & & - \\
\hline \multicolumn{17}{|c|}{ ART time of use (years) } \\
\hline$\leq 5$ & 3 & 4 & $0.01 *$ & 1.0 & 1 & 6 & 0.40 & - & 6 & 1 & 0.99 & - & 6 & 1 & 0.17 & - \\
\hline$\geq 6$ & 83 & 12 & & $\begin{array}{c}0.11 \\
(0.0-0.6)\end{array}$ & 36 & 59 & & - & 74 & 21 & & - & 49 & 46 & & - \\
\hline
\end{tabular}

* $\mathrm{p}<0.05$; †odds ratio; $¥$ Confidence interval 


\section{DISCUSSION}

The predominance of age lower than 39 years, steady relationship, and low household income among the study participants showed that women of reproductive age and socio-economic vulnerability were exposed to the virus through sexual transmission, in conformity with other studies $^{(4,12-13)}$. According to the current research, after diagnosis women with HIV/AIDS continued working actively to guarantee the income of their children and partners ${ }^{(14)}$.

In this study, most of the women declared that they had more than 10 years of education, which justifies the fact that some interviewees were aware of general information on family planning while living with HIV, indicating a better chance to understand and adhere to the recommendations regarding contraception. This higher level of education diverges from studies carried out in Africa ${ }^{(8-9)}$, where access to education is limited.

Most of the women in this study had lived with HIV for more than three years and had been using antiretroviral therapy since the diagnosis. Furthermore, they had learned of their serology during prenatal follow-up. This confirms the need at the national level for diagnosis and treatment with antiretroviral drugs among pregnant women and women of reproductive age $\mathrm{e}^{(5)}$, an important indicator for preventing vertical transmission of the virus. It should be mentioned that these same clinical characteristics were also found among African women ${ }^{(14-15)}$.

Considering that the discovery of infection among the current study participants took place during a prenatal examination, more than half of the women with HIV/ AIDS already had one or two children at the time of the interview, a number similar to that found in other studies ${ }^{(10,13-14)}$. Evidence shows that maternity is an important motivation for women with HIV/AIDS to continue with their life plans and adhere to the treatment ${ }^{(15)}$.

Despite the fact that most of the women with AIDS were within reproductive age and had active sexual lives, many did not want to have children in the future, a similar finding to that of other studies ${ }^{(9-10,12)}$. In the current research, this aspect could be associated with the fact that women have a lower household income, already had children, or it could be related to the lack of opportunity to discuss aspects related to reproduction with health professionals. Corroborating evidence shows that the option of not having children could be related to financial difficulties, because these women already have the number of children they consider adequate, because of the stigmatization in part of family members and health professionals, as well as concerns related to their children becoming orphans, vertical transmission, and serodiscordant partners ${ }^{(15-16)}$.

Regarding family planning, most of the interviewees were not using contraceptive methods according to the standards for people with HIV/AIDS, which are the use of condoms in all sexual relations. This increased the risk of undesired pregnancy as well as HIV reinfection. What was highlighted was one individual's use of male condoms; however, this percentage was considered low, taking into account that 100\% adherence is expected among these individuals. This low adherence to condoms matches the results of other studies $^{(7,14,16-17)}$. It emphasizes the need for health professionals to investigate the barriers to the adequate and consistent use of condoms as a self-care measure for preventing sexually transmitted infections (STIs) ${ }^{(18)}$

Some interviewees used oral contraceptives, which could indicate low access to this method by women being followed up at the outpatient unit ${ }^{(17)}$ or concerns related to the possibility of drug interaction with the ART ${ }^{(19)}$. Furthermore, an oral contraceptive is one more pill to be swallowed daily, with the possibility of unleashing adverse events such as nausea and irregular vaginal bleeding, contributing to the discontinuity of its use $\mathrm{e}^{(20)}$. Because hormonal contraception for women with HIV is a safe and unrestricted measure, health professionals should recommend the combination with condoms for preventing both undesired pregnancy and STIs ${ }^{(21)}$. Regarding tubal ligation, its lower percentage of usage converges with the literature ${ }^{(14)}$. However, it is necessary to motivate the adherence of Brazilian women with HIV/AIDS to non-defined methods. Furthermore, the possibility of a reduction in the adherence to condoms after tubal ligation indicates the importance of counseling on the continuity of their use for avoiding HIV reinfection and the acquisition of other infections ${ }^{(22)}$.

Although Brazil has a policy for prevention of vertical HIV transmission ${ }^{(22)}$, there is a gap related to receiving counseling on the forms of prevention of transmission and reproduction for those living with HIV, a similar situation found in studies conducted in African nations ${ }^{(16,23)}$. It is clear that women with HIV/AIDS are reluctant to talk about sexuality and their reproductive desire for fear of a negative reaction on the part of health professionals. These professional oftentimes consider the wish to have children as an act of irresponsibility and lack of information on the risks of HIV vertical transmission ${ }^{(24)}$. This is a disturbing finding, because limited knowledge may hamper the wish and the rights of women with HIV/AIDS to have children, thus increasing the risk of unplanned pregnancy and newborn exposure to the virus ${ }^{(9)}$.

This study revealed that women that did not receive information on family planning are more likely to have a tubal ligation, which can be linked to their limited knowledge and myths about other contraceptive methods. Therefore, it shows the need for health professionals to offer counseling to women with AIDS regarding the options, benefits, and risks of each method to promote their autonomy during decision-making ${ }^{(2,15)}$.

Steady partnership was a key factor in the desire to have children, similarly to other studies ${ }^{(9,25)}$. In general, women with HIV/AIDS that have a steady partnership often share their reproductive decisions with their partners, which leads to an important means of social support ${ }^{(2)}$. A relationship of trust between the studied patients and their partners was confirmed by the high percentage of women that revealed their serologic status to their partners, in line with other studies $^{(14-15,17)}$. There was a link between the fact that they already had children, their age, and their educational level, 
converging with the systematic review on fertility in people with $\mathrm{HIV}^{(2)}$, which indicated that young women are biologically more likely to have children, and those with higher educational levels have more access to information on reproductive rights and prevention of vertical transmission ${ }^{(23)}$.

Serodiscordant couples were identified as a hindrance to having children, matching with the evidence that exposed the dilemma women experience facing the risk of contamination from the conceptus and their partners ${ }^{(26)}$. Thus, counseling on reproduction is the recommendation for the couple, aimed at choosing the right time for conception, including discussion of other specific options for preventing HIV transmission, such as sperm washing and assisted reproduction.

Usage time of ART was also a predictor for women to bear children while infected with HIV, possibly because antiretrovirals promote improvement in health status and survival rate, factors that may favor maternity and reduce the risk of vertical transmission ${ }^{(25)}$. However, it was found that there was no link between the desire to have children and the length of time of using ART, in opposition to the speculations that indicate the increase in the wish to have children as the ART progresses ${ }^{(25)}$.

\section{CONCLUSION}

Knowledge of positive anti-HIV serology predominated during the prenatal period and the rejection of the wish to have more children. Age less than 39 years, higher educational level, and less ART time increased the chances of women with AIDS having already had children. Furthermore, women under 39 years of age and with a higher educational level had better chances of obtaining the right information on the possibility of having children while living with HIV. Having a steady relationship increased the chance of wishing to have children, while tubal ligation was high in women that did not receive counseling on family planning.

Despite the fact that Brazil has a policy on prevention of vertical transmission of HIV, efforts made to provide the means to increase the dialogue on family planning during outpatient care of Brazilian women with AIDS are critical to minimize the myths and provide conscious and safe decisions on reproductive choices. It is also necessary to guarantee access to contraceptive methods to all who wish to use them. Initiatives for this effect have an impact on improving knowledge, and on the attitudes and behavior regarding contraception for this target group.

The limitation of this study is represented by data collection in a single moment, and it was not possible to identify probable changes in behavior after the follow-up, including a lack of detail regarding the reasons for not using contraceptive methods. Despite this limitation, it is worth highlighting the importance of this study, taking into account that oftentimes the reproductive aspects and contraception methods for women with HIV/AIDS are not a priority during outpatient care, due to the stigma that surrounds the disease. As a consequence, the importance of new studies from the perspective of following up women with AIDS, and interventions oriented in this context, is emphasized.

\section{RESUMO}

Objetivo: Analisar aspectos reprodutivos e conhecimento sobre planejamento familiar de mulheres com síndrome da imunodeficiência adquirida (Aids). Método: Estudo transversal, descritivo, realizado de janeiro a dezembro de 2015, no ambulatório de infectologia de um hospital em Fortaleza, Ceará. Os dados foram coletados por meio de formulário, aplicado por entrevista em ambiente privativo. Resultados: Participaram do estudo 102 mulheres. A maioria delas teve conhecimento da sorologia positiva para vírus da imunodeficiência humana (HIV) durante o pré-natal (96,1\%), e estas não pretendiam mais ter filhos (63,7\%). Mulheres com idade menor que 39 anos, maior escolaridade e menor tempo de terapia antirretroviral tiveram maiores chances de ter filhos $(p \leq 0,05)$. Mulheres com idade menor que 39 anos e maior escolaridade tiveram maiores chances de ter informações corretas sobre ter filhos na vigência do HIV ( $p \leq 0,05)$. Ter parceiro fixo aumentou a chance de desejar ter filhos, enquanto a laqueadura tubária foi maior em mulheres que não receberam orientações sobre planejamento familiar. Conclusão: A maioria das mulheres com Aids não pretendem mais ter filhos. O conhecimento sobre o planejamento familiar foi limitado por falta de orientações pelos profissionais de saúde.

\section{DESCRITORES}

HIV; Síndrome da Imunodeficiência Adquirida; Reprodução; Anticoncepção; Planejamento Familiar.

\section{RESUMEN}

Objetivo: Analizar aspectos reproductivos y el conocimiento acerca de planificación familiar de las mujeres con síndrome de inmunodeficiencia adquirida (SIDA). Método: Estudio transversal, descriptivo realizado de enero a diciembre de 2015, en la sala de enfermedades infecciosas de un hospital de Fortaleza, Ceará. Los datos fueron recolectados a través de una entrevista semiestructurada de forma de cuestionario en un ámbito privado. Resultados: El estudio incluyó a 102 mujeres. La mayoría de ellos tenían conocimiento de ser seropositivas para el virus de la inmunodeficiencia humana (VIH) durante la atención prenatal (96,1\%), y que no tenía intención de tener más hijos (63,7\%). Mujeres menores de 39 años, con educación superior y terapia antirretroviral más corta eran más propensas a tener hijos $(\mathrm{p}=0,05)$. Mujeres con edades de menos de 39 años y más educación tenían más probabilidades de tener la información correcta acerca de tener hijos en presencia del VIH $(p=0,05)$. Tener pareja estable aumentó la posibilidad de desear tener hijos, mientras que la ligadura de trompas fue mayor en las mujeres que no han recibido orientación sobre la planificación familiar. Conclusión: La mayoría de las mujeres con SIDA no tienen intención de tener hijos. El conocimiento acerca de la planificación familiar se vio limitada por la falta de orientación por los profesionales de la salud.

\section{DESCRIPTORES}

VIH; Síndrome de Inmunodeficiencia Adquirida; Reproducción; Anticoncepción; Planificación Familiar. 


\section{REFERENCES}

1. World Health Organization. Global Health Observatory (GHO) data. Number of women living with HIV [Internet]. Geneva: WHO; 2015 [cited 2015 Sept 10]. Available from: http://www.who.int/gho/hiv/epidemic_status/cases_adults_women_children/en/

2. BerhanY, Berhan A. Meta-analyses of fertility desires of people living with HIV. BMC Public Health.2013;13:409.

3. Phillips S, Steyn P, TemmermanM. Contraceptive options for women living with HIV. Best Pract Res Clin Obstet Gynaecol. 2014;28(6):881-90.

4. Yotebieng M, Norris A, Chalachala JL, MatumonaY, Ramadhani HO, Behets F. Fertility desires, unmet need for family planning, and unwanted pregnancies among HIV-infected women in care in Kinshasa, DR Congo. Pan Afr Med J. 2015; 20:235.

5. Jerome JS, Galvão MTG, Lindau ST. Brazilian mothers with HIV: experiences with diagnosis and treatment in a human rights based health care system. AIDS Care. 2012; 24(4):491-5.

6. Boletim Epidemiológico HIV/Aids. Brasília: Ministério da Saúde; Secretaria de Vigilância em Saúde, Departamento de DST, Aids e Hepatites Virais. 2015;4(1).

7. Loutf M., Khosla R, Narasimhan M. Advancing the sexual and reproductive health and human rights of women living with HIV. J Int AIDS Soc. 2015; 18(Suppl 5):20760.

8. Onono M, Blat C, Miles S, Steinfeld R, Wekesa P, Bukusi EA, et al. Impact of family planning health talks by lay health workers on contraceptive knowledge and attitudes among HIV-infected patients in rural Kenya. Patient Educ Couns. 2014;94(3):438-41.

9. Mmbaga EJ, Leyna GH, Ezekiel MJ, Kakoko DC. Fertility desire and intention of people living with HIV/AIDS in Tanzania: a call for restructuring care and treatment services. BMC Public Health. 2013;13:86.

10. Ngugi EW, Kim AA, Nyoka R, Ng'ang'a L, Mukui I, Ng'eno B, et al. Contraceptive practices and fertility desires amonghiv-infected and uninfected women in Kenya: results from a nationally representative study. J Acquir Immune Defic Syndr. 2014;66 Suppl 1:S75-81.

11. Joint United Nations (UNAIDS). Programme on HIV/AIDS. The Gap Report [Internet]. Geneva; 2014 [cited 2016 Feb 16]. Available from: http://www.unaids.org/en/resources/campaigns/2014/2014gapreport/gapreport

12. Patel R, Baum S, Grossman D, Steinfeld R, Onono M, Cohen C, et al. HIV-positive men's experiences with integrated family planning and HIV services in western Kenya: integration fosters male involvement. AIDS Patient Care STDS. 2014;28(8):418-24.

13. Newmann SJ, Grossman D, Blat C, Onono M, Steinfeld R, Bukusi EA, et al. Does integrating family planning into HIV care and treatment impact intention to use contraception? Patient perspectives from HIV-infected individuals in Nyanza Province, Kenya. Int J Gynaecol Obstet. 2013;123(Suppl 1):e16-23.

14. Melaku YA, Zeleke EG. Contraceptive utilization and associated factors among HIV positive women on chronic follow up care in Tigray Region, Northern Ethiopia: a cross sectional study. PLoS One. 2014;9(4):e94682.

15. Matthews LT, Crankshaw T, Giddy J, Kaida A, Smit JA, Ware NC, et al. Reproductive decision-making and periconception practices among HIV-positive men and women attending HIV services in Durban, South Africa. AIDS Behav. 2013;17(2):461-70.

16. Schaan MM, Taylor M, Marlink, R. Reproductive behaviour among women on antiretroviral therapy in Botswana: mismatched pregnancy plans and contraceptive use. Afr J Res AIDS. 2014;13(3):305-11.

17. Yotebieng M, Norris A, Chalachala JL, MatumonaY, Ramadhani HO, Behets F. Fertility desires, unmet need for family planning, and unwanted pregnancies among HIV-infected women in care in Kinshasa, DR Congo. Pan Afr Med J. 2015;20:235.

18. Alene KA. Consistent condom use among sexually active HIV positive women in Amhara region, Ethiopia. Open Access J Contracept. 2014;5:85-90.

19. Phillips S, Steyn P, Temmerman M. Contraceptive options for women living with HIV. Best Pract Res Clin Obstet Gynaecol. 2014;28(6):881-90.

20. Nanda K, Morrison CS, Kwok C, Byamugisha J, Jones L, Sriplienchan S, et al. Discontinuation of oral contraceptives and depot medroxyprogesterone acetate among women with and without HIV in Uganda, Zimbabwe and Thailand. Contraception. 2011;83(6):542-8.

21. World Health Organization. Hormonal contraception and HIV: technical statement [Internet]. Geneva: WHO; 2012 [cited 2016 Apr 08]. Available from: http://www.natap.org/2012/HIV/WHOHormonalcontraceptionHIV.pdf

22. Brasil. Ministério da Saúde; Secretaria de Vigilância em Saúde, Departamento de DST, Aids e Hepatites Virais. Recomendações para profilaxia da transmissão vertical do HIV e terapia antirretroviral em gestantes [Internet]. Brasília; 2010 [citado 2016 abr. 08]. Disponível em: http://www.aids.gov.br/sites/default/files/consenso_gestantes_2010_vf.pdf

23. Birhane T, Tessema GA, Alene KA, Dadi AF. Knowledge of pregnant women on mother-to-child transmission of HIV in Meket District, Northeast Ethiopia. J Pregnancy. 2015;2015:960830. DOI: 10.1155/2015/960830.

24. Caldas MAG, Porangaba SCF, Melo ES, Gir E, Reis RK. Perception of the nursing team on pregnancy concerning infection caused by HIV. Rev RENE. 2015;16(1):28-37.

25. Fatimetu Mohammed F, Assefa N. Determinants of desire for children among HIV-positive women in the Afar Region, Ethiopia: case control study. PLoS One. 2016; 11(3):e0150566.

26. Hailemariam TG, Kassie GM, Sisay MM. Sexual life and fertility desire in long-term HIV serodiscordant couples in Addis Ababa, Ethiopia: a grounded theory study. BMC Public Health. 2012;12:900. 